\title{
The Difference between Students Critical Thinking Skill Using Problem Based Learning and Think Pairs Share on Coordination System Material
}

\author{
Abidinsyah, Siti Ramdiah \\ Biology Education Department \\ STKIP PGRI Banjarmasin \\ Banjarmasin, Indonesia \\ sitiramdiah@gmail.com
}

\begin{abstract}
Global development requires education to always empower higher order thinking skills (HOTs). These skills are a sign that somebody has learned and thought to compete globally. Therefore, education has a pertinent role in preparing qualified human resources. In line with this, the teaching of biology has a potential to empower these HOTs, one of which is critical thinking skill. The purpose of this study was to determine the differences of students' critical thinking skill between students who were taught by using Think Pair Share (TPS) model and Problem Based Learning (PBL) models. The quasi-experimental study using pretest-posttest design non-equivalent control group design was employed in this study. The control group was taught by using TPS while the experimental group was taught by using PBL model. 51 students of the eleventh grade of senior high schools in Banjarmasin were involved. The data were collected from the essay tests. Meanwhile, in regard to the critical thinking skill assessment, it referred to [1]. Then, the data were analyzed through ANACOVA with SPSS 17.0 program. The results of this study showed significant information on the results of a pretest to posttest scores for the critical thinking skills of $0.004<0.05$. These results pointed out that the students who were taught by using PBL have better critical thinking skill than those who were taught by using TPS.
\end{abstract}

Keywords-Critical Thinking, PBL Model, TPS Model

\section{INTRODUCTION}

Teaching and learning process is an educational process which offers the opportunity to students to explore their inner potential. The teaching and learning process guides the students to experience the changes which later called learning. The changes as the result of the learning process can be reflected from the behavior changes, skill or ability improvement, habit or the changes on other individual aspects. The result of teaching and learning process equips students to be able to solve life challenges. Therefore, the teaching and learning process underlines an important part especially on the students' thinking skill empowerment.

Empowering students thinking skill can be trained through several teaching designs. Then, the teaching designs can be integrated with specific teaching models which potentially can improve students thinking skill. The teaching design in this matter is the process of teaching and learning process which explores students 'ability and skill to find out, process, and evaluate information critically. The well planned teaching and learning process will be able to empower students' critical thinking. It shows how important a teaching and learning process in educational world.

The quality of human resources took an important part to be improved and developed in which the parameter is the academic result of the students [2]. In the same line with [2], Ref. [3] mentioned that the teaching and learning process is essentially the teaching of chained thinking which focuses on particular mental skill, for example critical thinking.

In line with the ideas above, the teaching of Biology has big potential in empowering students' critical thinking. The Biology teaching and learning process trains students to participate and get involved in delivering questions, finding information, and conducting investigation. However, the fact shows that one of the problems faced by the teacher in the teaching and learning process is the lack of understanding toward the concept of the material. It means that students' critical thinking level is still low.

The teaching of Biology in senior high school itself is still dominated by unsuccessful result, which is shown by students' scores that are under or on the minimum completeness criteria. Most problem lies on the teachers' style in dominating the class and create students minimum involvement. Thus, the teaching and learning process seems monotones and lack of variation, especially in terms of the teaching model and teaching method [4].

This statement is supported by [5] who stated that based on interview of Biology teachers; it was found that the teaching of Biology is dominated by knowledge aspect instead of thinking aspect. There are no specific activities which support the teaching and learning process with students activeness oriented. There are also no activities which create exposure for the students to be able to gain, get familiar, understand, and apply the knowledge concept meaningfully.

Based on the issues above, the researchers believe that innovation especially in the teaching and learning process is 
highly needed. The implementation of Problem Based Learning (PBL) is sufficiently relevant for its potential to provide the chance to practice the students' critical thinking. PBL model is an innovative teaching model where students can actively get involved in solving the problem scientifically. Besides that model, another teaching model with similar ideas is Think Pair Share (TPS). The TPS model helps students to interpret their ideas and construct their understanding through discussion. With this model, it is hoped that there is a fun, active, creative, and effective learning environment. Therefore, the study is aimed on finding out the differences between PBL and TPS model in improving senior high school students' critical thinking in Banjarmasin.

\section{RESEARCH METHOD}

This research was a quasi experimental study with pretestposttest non-equivalent control group design. The population of this study was the students of XI IPA of all SMAN of Banjarmasin. Before conducting the study, the researcher conducted a sample equivalence test in order to determine the control and experiment group. The result of the test showed that the academic level of the students of XI IPA 1 of SMAN 12 and XI IPA 3 of SMAN 13 was equal. Later, it was decided that the students of XI IPA 1 of SMAN 12 would be taught with TPS model, while XI IPA 3 of SMAN 13 would be taught with PBL model. The data of this study were obtained through pretest and posttest. Both test were given in form of essay and scored by using the critical thinking scoring system adapted from [1]. The score was in range of 0- 4. The data were analyzed by using ANACOVA test using SPSS 17.0 program.

\section{RESUlT AND DiSCUSSION}

Based on the normality test result through KolmogorovSmirnov, it was shown that the data were distributed normally (0.273), then the homogeneity test through Levene's test showed that variant between data was homogeneous (0.854). The analytical result for the differences between PBL learning model and TPS model toward students' analytical thinking are shown in Table 1.

TABLE I. The Summary Of Anacova Result On Students CRITICAL THINKING SKILLS

\begin{tabular}{|l|l|l|l|l|c|}
\hline \multicolumn{1}{|c|}{ Source } & $\begin{array}{l}\text { Type III Sum of } \\
\text { Squares }\end{array}$ & \multicolumn{1}{|c|}{ Df } & $\begin{array}{c}\text { Mean } \\
\text { Square }\end{array}$ & \multicolumn{1}{|c|}{ F } & Sig. \\
\hline $\begin{array}{l}\text { Corrected } \\
\text { Model }\end{array}$ & $3225.09^{\mathrm{a}}$ & 2 & 1612.55 & 27.54 & 0.000 \\
\hline Intercept & 7567.98 & 1 & 7567.98 & 129.25 & 0.000 \\
\hline Pretest & 540.01 & 1 & 540.01 & 9.22 & 0.004 \\
\hline Model & 3185.15 & 1 & 3185.15 & 54.40 & 0.000 \\
\hline Error & 2810.45 & 48 & 58.55 & & \\
\hline Total & 147656.25 & 51 & & & \\
\hline $\begin{array}{l}\text { Corrected } \\
\text { Total }\end{array}$ & 6035.54 & 50 & & & \\
\hline
\end{tabular}

Table 1 above shows that there were significant differences between learning model and students' critical thinking. The differences are represented by significance value $(\mathrm{sig})=0.000$
$<0.05$. Further, Heterogeneity test shows significant result was $0.004<0.05$ which means there were differences on the students' critical thinking. Those data were also supported by the comparison result on improvement of PBL and TPS learning method toward students' critical thinking skill in Table 2 .

TABLE II. The COMPARISON ReSUlt BetweEn PBL LEARNING Model IMPROVEMENT AND TPS LEARNING MODEL IMPROVEMENT TOWARD STUDENTS' CRITICAL THINKING

\begin{tabular}{|l|l|l|l|l|}
\hline \multirow{2}{*}{$\begin{array}{c}\text { Learning } \\
\text { Strategy }\end{array}$} & \multicolumn{2}{|c|}{ Average } & \multirow{2}{*}{ Improvement } & $\begin{array}{c}\text { Improvement } \\
(\%)\end{array}$ \\
\cline { 2 - 3 } & Pretest & Postest & & \multicolumn{1}{|c|}{ Im } \\
\hline PBL & 12.50 & 59.53 & 47.03 & 376.29 \\
\hline TPS & 18.02 & 45.00 & 26.97 & 149.71 \\
\hline
\end{tabular}

Based on Table 2 above, if the average corrected-score of students' critical thinking is in percentages then the class which was facilitated by PBL learning model had 47.03 score improvement or $24.40 \%$ higher than TPS learning model. The data result above means PBL learning model has a better potential to improve students' critical thinking skills.

This research gave information that learning model influences students' critical thinking. The PBL learning model is assumed to give a positive effect to students' critical thinking. If we analyze the data thoroughly, the result implies that PBL stages learning model excess the TPS model. The PBL stages give the problems or questions related to the learning material to trigger the students' activity for gaining the information as much as possible, after that the students in group investigate and try to find the solution toward the problem given. On the next stage, students are able to develop their thought through analysis and evaluation the investigation process.

PBL successfulness depends on how good our ability in giving realistic problems to the students so we can help the students to develop problem solving skill and self-directed [6]. In addition, PBL tries to help the students to become independent learner and self-regulated [7].

According to [8] PBL applies learning approach which uses an authentic problem as learning sources, so that the students are trained to have higher order thinking skill and develop their character through the problems and real life activities. Additionally, PBL model for problem solving uses scientific learning approach based on deductive and inductive learning process. This learning process is conducted systematically and empirically [9].

Then, the learning style by group work plays important role related to motivation and responsibility. It is assumed that the students' actively involvement as well as curiosity, challenge, and the task given are the reasons. It also urges the students to do the investigation, dialogue, and critical thinking development together as well. Therefore, PBL has a potential to direct the students learning to be meaningful [10]. 


\section{CONCLUSION}

This study showed significant differences between learning model in relation to students' critical thinking. This study pointed out that the students who were taught by using PBL have better critical thinking skill than those who were taught by using TPS.

\section{REFERENCES}

[1] D. Hart, "Authentic Assesment A handbook for Educators. California, New York : Addison Wesley Publishing company, 1994.

[2] S. Ramdiah, "Learning strategy equalizing students' achievement, metacognitive, and critical thinking skills" , American Journal of Educational Research, vol. 2, no. 8, pp. 577-584, 2014 Available online at http://pubs.sciepub.com/education/2/8/3.

[3] Costa, A.L. 2008. The School as a Home for the Mind: Creating Mindful Curriculum, Instruction, and Dialogue (2th edition). Thousand
Oaks: Corwin Press. Dari BooksGoogle, (Online), (http://books.google.co.id/books?id)

[4] Rapikah, "Pengaruh Model Pembelajaran Think Pair Share (TPS) Terhadap Keterampilan Berpikir Kritis Siswa Kelas XI IPA SMAN 13 Banjarmasin”, 2016. unpublished.

[5] P. Eggen, and D, Kauchak, "Strategi dan Model Pembelajaran. Mengajarkan Konten dan Keterampilan Berpikir" , Terjemahan oleh Satrio Wahono. Jakarta: Indeks, 2016.

[6] R, Arends, "Learning to Teach. ( $7^{\text {th }}$ edition)", New York: Mc Grow Hill, 2008.

[7] Hamzah dan M. Nurdin, "Belajar Dengan Pendekatan PAILKEM: Pembelajaran Aktif, Inovatif, Lingkungan, Kreatif, Efektif, Menarik", Jakarta: Bumi Aksara, 2011.

[8] S. M. Sumantri, "Strategi Pembelajaran: Teori Dan Praktek Tingkatan Pendidikan Dasar", Jakarta: rajawali pers, 2015.

[9] S. Ramdiah, R. Mayasari dan Wahyunita, "Pengaruh pembelajaran PBL terhadap hasil belajar kognitif biologi siswa putra dan putri kelas VII SMPIT”, Jurnal Ilmiah BioSmart, vol 3, no 2, Juli 2016, pp. 53-61. 